\title{
COMMENTARY
}

\section{Agritourism around the globe: Definitions, authenticity, and potential controversy}

\author{
R. David Lamie ${ }^{\text {* }}$ \\ Clemson University \\ Lisa Chase ${ }^{b}$ \\ University of Vermont Extension \\ Emilio Chiodo $^{c}$ \\ University of Teramo
}

Lori Dickes $^{\mathrm{d}}$
Clemson University

\author{
Sharon Flanigan ${ }^{\mathrm{e}}$ \\ The James Hutton Institute
}

Claudia Schmidt ${ }^{\mathrm{f}}$

Penn State University

Thomas Streifeneder $\mathrm{g}$

Eurac Research

Submitted November 17, 2020 / Accepted November 17, 2020 / Published online March 22, 2021

Citation: Lamie, R. D., Chase, L., Chiodo, E., Dickes, L., Flanigan, S., Schmidt, C., \& Streifeneder, T (2021). Agritourism around the globe: Definitions, authenticity, and potential controversy. Journal of Agriculture, Food Systems, and Community Development, 10(2), 573-577. https://doi.org/10.5304/jafscd.2021.102.002

Copyright (C 2021 by the Authors. Published by the Lyson Center for Civic Agriculture and Food Systems. Open access under CC-BY license.

\begin{abstract}
This commentary identifies the variability in definitions of agritourism that exists in a variety of different countries, discusses reasons why this variability might produce problems, and provides

a * Corresponding author: R. David Lamie, Professor, Sandhill Research and Education Center, Department of Agricultural Sciences, Clemson University; 900 Clemson Road, Columbia, SC 29229 USA; +1-803-521-4355; dlamie@clemson.edu

b Lisa Chase, Extension Professor, University of Vermont Extension, Vermont Tourism Research Center; 130 Austine Drive, Suite 300; Brattleboro, VT 05301-7040 USA; +1-802257-7967 x311; Lisa.chase@uvm.edu

c Emilio Chiodo, Faculty of Bioscience and Technology for Food, Agriculture and Environment, Campus, University of Teramo; Via R. Balzarini 1; 64100 Teramo, Italy; +00390861 266898; echiodo@unite.it

d Lori Dickes, Associate Professor and Associate Chair and Program Director (Public Administration), Parks, Recreation and Tourism Management; Clemson University; +1-864-6567831; lorid@g.clemson.edu
\end{abstract}

examples of efforts to harmonize these definitions, including an ongoing international dialogue on the topic.

\section{Keywords}

Agritourism, Definitions, International, Consensus, Research, Collaboration

\footnotetext{
e Sharon Flanigan, Researcher in Rural Social Science; Social, Economic, and Geographical Sciences (SEGS) Department, The James Hutton Institute; Craigiebuckler; Aberdeen AB15 8QH Scotland UK; +44 (0)1224 395301; Sharon.flanigan@hutton.ac.uk

${ }^{f}$ Claudia Schmidt, Assistant Professor, Agricultural Economics, Sociology, and Education, Penn State University; 207-D Armsby Building; University Park, PA 16801 USA; +1-814-863-8633; cschmidt@psu.edu

$\mathrm{g}$ Thomas Streifeneder, Head of Institute, Eurac Research, Institute for Regional Development; Drususallee 1; 39100 Bozen/Bolzano, Italy; +390471 055315; Thomas.Streifeneder@eurac.edu
} 
$\mathrm{T}$ he practice of gathering on farms, ranches, and vineyards may be as old as the invention of agriculture. Modern or proto-agritourism probably started in South Tyrol, Italy, during the second half of the 19th century, when aristocrats escaped heat in the summertime and went to stay at mountain farms (villeggiatura/Sommerfrische/summer retreat). Similar patterns of migration are well documented in South Carolina, where wealthy plantation owners migrated from the Lowcountry to the Upcountry for the summer. Over the past 35 years, that practice has been named, defined, legislated, and marketed as the concept of agritourism and has spread throughout the globe.

In 1985, the first national law to recognize and define agritourism (agriturismo) was passed in Italy. It focused on overnight stays that support the restoration of farm buildings and the diversification of income sources for working farms in rural areas. Today, agritourism - and several related terms and concepts - can be found throughout the world with a variety of definitions and practices. In many places, the operational definition of agritourism has grown to embrace a wide variety of related forms of rural tourism that vaguely resemble the original concept of being closely linked to working farms.

Differences in how agritourism is conceived and defined influence the larger policy and regulatory environment around agritourism enterprises, whether and how they are linked to potential supporting organizations, and how they are viewed in the eyes of consumers seeking various levels of authenticity in their agritourism experience. Additionally, how agritourism enterprises are defined and identified by government(s) and policymakers determines how they are treated by taxing and regulating authorities. If the definitions are too loose, they can result in an erosion of overall tourism product quality. If too restrictive, they can result in agritourism being considered too elitist or too small to matter. This has led to confusion and controversy as agritourism has grown in popularity and has been appropriated (some would say co-opted) for marketing and other purposes.

Having a consistent global understanding of agritourism would be useful for developing policies, conducting research, and implementing programs that support working farms and rural com- munities. Some countries have opted for more restrictive definitions of "authentic agritourism" than others. In many cases, the decisions concerning definitions of agritourism have been thoughtfully considered. In other geographies, this conversation is only just beginning.

The Institute for Regional Development at Eurac Research in Bolzano, Italy, is collaborating with a group of colleagues around the globe to develop a shared understanding of agritourism with an emphasis on authenticity. They hope to better understand the motivations for inclusion or exclusion of various definitional elements so they can help support decisions by agritourism leaders and inform policy related to agritourism.

They are building on a foundation of previous work examining definitions of agritourism. A widely used typology by a team in Scotland posited a comprehensive view of agritourism based on existing literature perspectives (Phillip, Hunter, \& Blackstock, 2010; see Figure 1) and was subsequently developed with empirical perspectives from across Scotland (Flanigan, Blackstock, \& Hunter, 2014; see Figure 2). In each of these theoretical frameworks, the nature of interaction and authenticity (in terms of place and activity) were found to be important discriminators of different types of agritourism products. A researcher based in Italy argued for a stricter definition of authentic agritourism, separate from countryside tourism (Streifeneder, 2016; see Figure 3). Using this narrower authenticity definition, "pure" agritourism operations are largely focused in and around a working farm. Other peripheral activities, such as rural tourism activities, even if on a farm, are not considered authentic.

In response to the conflicting definitions, a multistate team in the U.S. created a conceptual framework for understanding agritourism: the core of agritourism consists of activities that are deeply connected to agriculture and take place on a working farm (Chase, Stewart, Schilling, Smith, \& Walk, 2018; see Figure 4). There seems to be general agreement about the core, but less agreement within the periphery, as some consider these activities to be included in agritourism while others do not.

Several of those involved in this work were able to participate in the First World Congress on 
Agritourism in Bolzano, Italy, November 2018.

There, Thomas Streifeneder, the conference host, advocated for an emphasis on "authenticity" in agritourism. Several presenters, including Lisa Chase, shared a variety of definitions and under- standings of agritourism from around the globe, including those that were considered more or less traditionally authentic. In Scotland, definitions continue to evolve. The concept is becoming increasingly operationalized as connections to food pro-

Figure 1. A Typology for Defining Agritourism

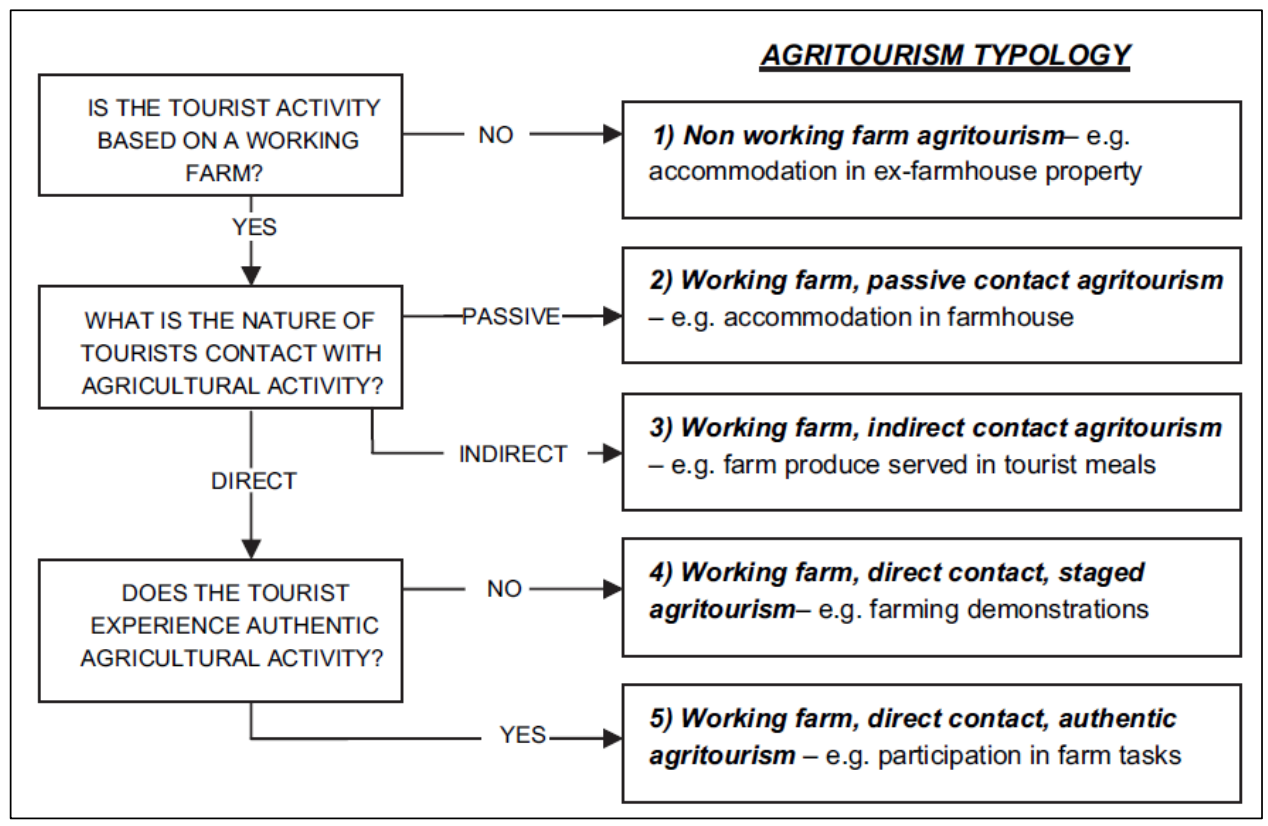

Source: Phillip, Hunter, \& Blackstock (2010).

Figure 2. A Revised Typology for Defining Agritourism

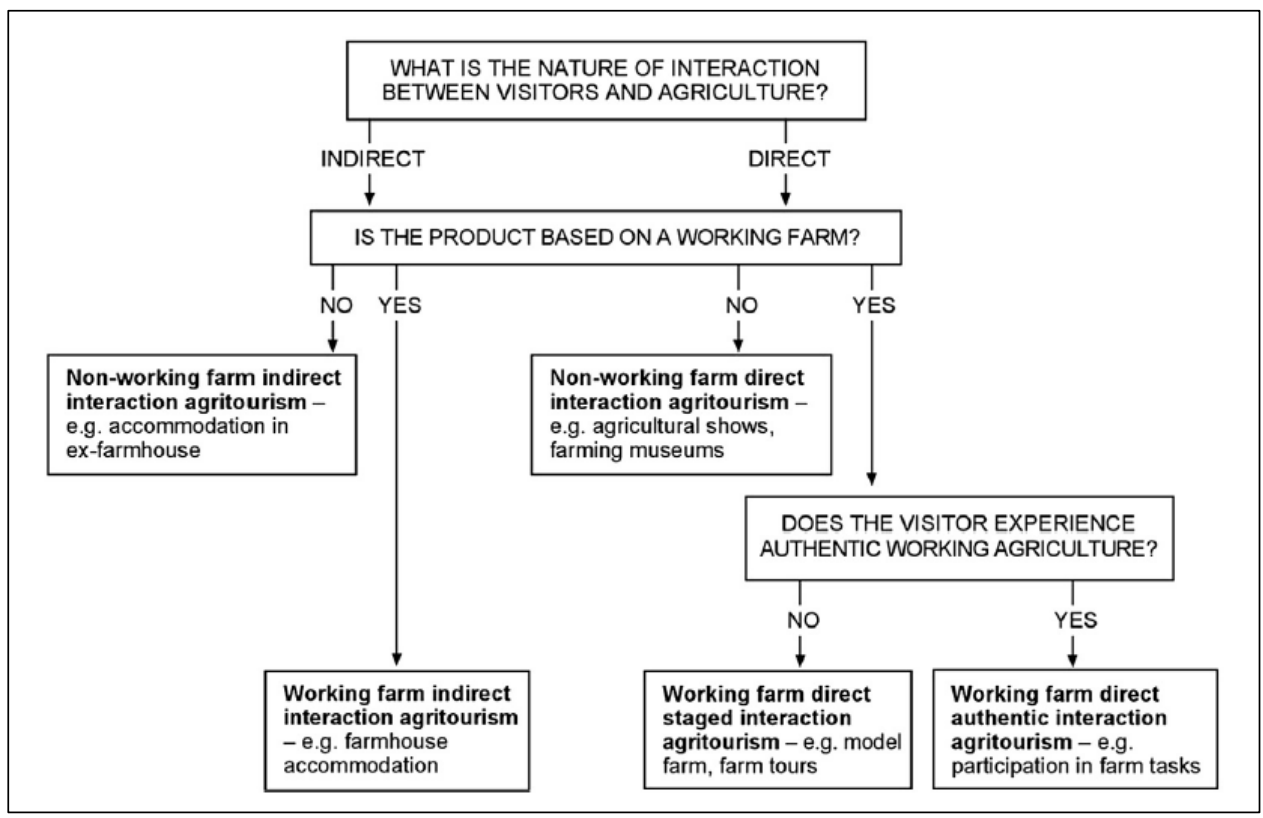

Source: Flanigan, Blackstock, \& Hunter (2014). 
Figure 3. Distinctive Features of Authentic Agritourism and Countryside Tourism

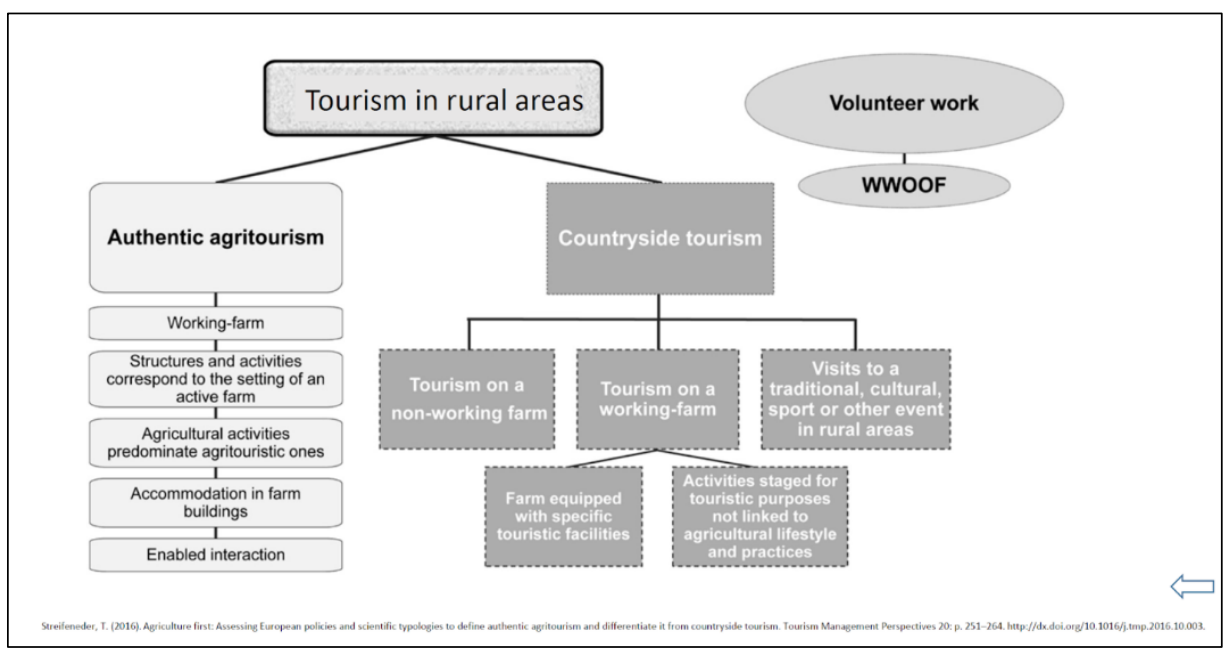

Adapted from Streifeneder (2016, p. 259).

Figure 4. Conceptual Framework for Understanding Agritourism in the U.S. In the U.S., the core activities are generally accepted as agritourism, while the peripheral tiers contain activities that may or may not be considered agritourism and can lead to misunderstanding and controversy.

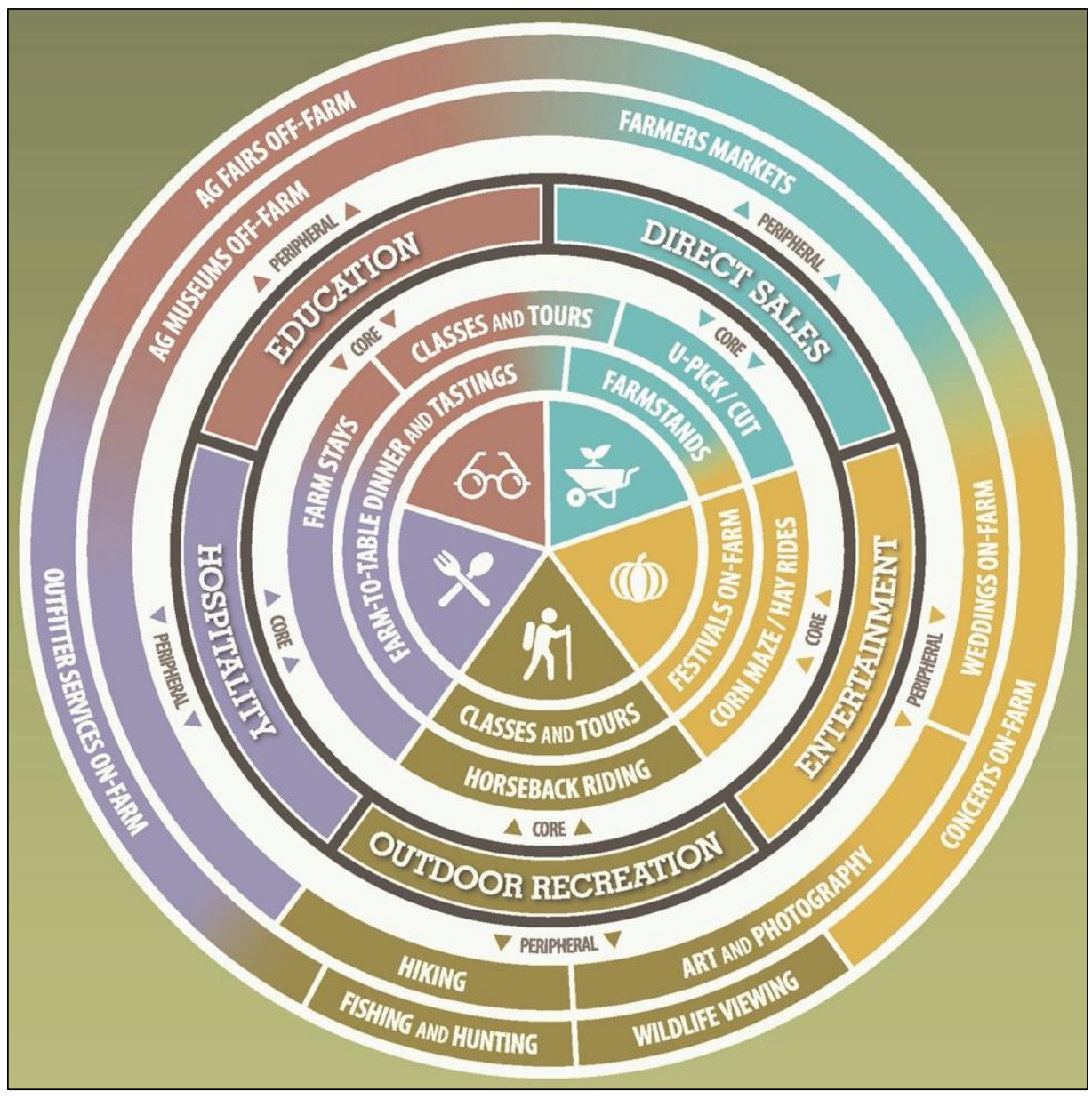


duction and food tourism, and more strict requirements for agritourism products to be based on a working farm were recently endorsed at the country's first conference, held virtually in 2020 .

One result of the Bolzano World Congress was the expansion of a USDA-funded project focused on better understanding agritourism in the United States. Through connections developed at the World Congress, this project is being extended into selected European and South American countries and Canada. Plans underway for international agritourism scholars to work collaboratively may also pave the way for discussion and resolution of persistent definitional issues.

As agritourism grows in popularity around the world, it is becoming increasingly difficult to "police" the usage of the term and the corresponding quality of experiences. In response, certification programs have been developed in some regions (e.g., Red Rooster in South Tyrol; https://www.redrooster.it/en/) to provide some measure of quality control for consumers and a level of professionalism for suppliers.

The process of developing a clear, consistent definition of agritourism is underway, and perspectives and voices from around the world are invited to participate. As this research continues, input from agritourism practitioners, scholars, policy-makers, and others is necessary to help inform this work.

\section{References}

Chase, L. C., Stewart, M., Schilling, B., Smith, B., \& Walk, M. (2018). Agritourism: Toward a conceptual framework for industry analysis. Journal of Agriculture, Food Systems, and Community Development, 8(1), 13-19. https://doi.org/10.5304/jafscd.2018.081.016

Flanigan, S., Blackstock, K., \& Hunter, C. (2014). Agritourism from the perspective of providers and visitors: a typologybased study. Tourism Management, 40, 394-405. https://doi.org/10.1016/j.tourman.2013.07.004

Phillip, S., Hunter, C., \& Blackstock, K. (2010). A typology for defining agritourism. Tourism Management, 31(6), $754-758$. http://doi.org/10.1016/i.tourman.2009.08.001

Streifeneder, T. (2016). Agriculture first: Assessing European policies and scientific typologies to define authentic agritourism and differentiate it from countryside tourism. Tourism Management Perspectives, 20(October), 251-264. https://doi.org/10.1016/j.tmp.2016.10.003 